\title{
Preparation Methods for Improving PEEK's Bioactivity for Orthopedic and Dental Application: A Review
}

\author{
Davood Almasi, ${ }^{1}$ Nida Iqbal, ${ }^{2}$ Maliheh Sadeghi, ${ }^{3}$ Izman Sudin, ${ }^{1}$ \\ Mohammed Rafiq Abdul Kadir, ${ }^{2}$ and Tunku Kamarul ${ }^{4}$ \\ ${ }^{1}$ Department of Materials, Manufacturing and Industrial Engineering, Faculty of Mechanical Engineering, \\ Universiti Teknologi Malaysia, 81310 Skudai, Johor, Malaysia \\ ${ }^{2}$ Medical Implant Technology Group (MEDITEG), Faculty of Bioscience and Medical Engineering, Universiti Teknologi Malaysia, \\ 81310 Skudai, Johor, Malaysia \\ ${ }^{3}$ Faculty of Chemical and Energy Engineering, Universiti Teknologi Malaysia, 81310 Skudai, Johor, Malaysia \\ ${ }^{4}$ Department of Orthopaedic Surgery, NOCERAL, Faculty of Medicine, University of Malaya, 50603 Kuala Lumpur, Malaysia
}

Correspondence should be addressed to Izman Sudin; izman@utm.my

Received 3 November 2015; Revised 25 February 2016; Accepted 7 March 2016

Academic Editor: Rosalind Labow

Copyright (C) 2016 Davood Almasi et al. This is an open access article distributed under the Creative Commons Attribution License, which permits unrestricted use, distribution, and reproduction in any medium, provided the original work is properly cited.

\begin{abstract}
There is an increased interest in the use of polyether ether ketone (PEEK) for orthopedic and dental implant applications due to its elastic modulus close to that of bone, biocompatibility, and its radiolucent properties. However, PEEK is still categorized as bioinert due to its low integration with surrounding tissues. Many studies have reported on methods to increase the bioactivity of PEEK, but there is still one-preparation method for preparing bioactive PEEK implant where the produced implant with desirable mechanical and bioactivity properties is required. The aim of this review is to present the progress of the preparation methods for improvement of the bioactivity of PEEK and to discuss the strengths and weaknesses of the existing methods.
\end{abstract}

\section{Introduction}

PEEK with high chemical resistance, radiolucency, mechanical characteristics compared to those of human bones [16], and local inflammation and stress shielding problem of the metallic implant $[7,8]$ has become a very interesting biomaterial for scientists and a promising good alternative for metallic implants. The radiolucency of PEEK is vital especially for the postoperative radiotherapy follows the surgical removal of the tumor. The presence of metallic implants can change the local dose distribution $[9,10]$. In addition, it can be repeatedly sterilized and shaped by machining and heat contouring to fit the contour of bones [11]. PEEK has been used for load bearing orthopedic applications such as spinal cage, dental implant, and screws $[12,13]$. Despite these excellent properties, PEEK is still categorized as bioinert due to its very low reaction with the surrounding tissue, which limits its potential applications [1]. For overcoming this problem, several methods have been proposed which can broadly be divided into two main categories: incorporation of bioactive materials such as hydroxyapatite (HA) and titanium dioxide $\left(\mathrm{TiO}_{2}\right)$ into PEEK composite and surface treatment techniques such as laser surface modification, coating with the bioactive material, and wet chemical treatment [14-22].

A review of presently available methods to improve the bioactivity of PEEK was conducted with the aim of providing sufficient information regarding known preparation techniques and to compare the pros and cons of each of these methods. It is hoped that this will lead to a better understanding of the methods available and a clear reason as to why a method should be ultimately chosen by a researcher or an implant manufacturer.

\section{PEEK's Bioactivity}

One of the important factors that lead to successful implantation is the biological response to the implant, which very 


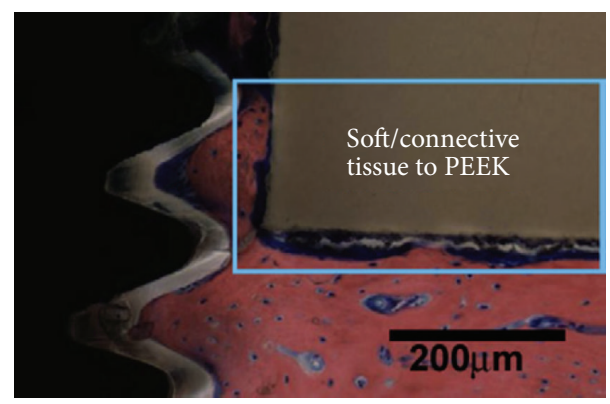

FIGURE 1: PEEK bioinert properties and growth of soft tissue around it [30].

much depends on the bioactivity of the implant. A material is considered bioactive if it obtains a particular biological answer to the interface of the element, which ends in the formation of a bond between the tissue and the substance [23].

When an implant is placed in the body, molecules of water are one of the first molecules to reach the implant surface. The absorption of proteins on the surface is influenced by the initially adsorbed water molecules and is affected by surface structure, chemistry, charge, and wettability [24]. Subsequently, these adsorbed proteins influence cellular interactions and eventually tissue growth $[25,26]$. Surfaces with moderate hydrophilicity properties showed the best interactions with cells and surrounding tissues [27].

An essential problem with most polymers, including PEEK, is their low-surface energy. This hydrophobic property of the surface can reduce cellular adhesion. The lack of response from the biological environment caused PEEK to be categorized as bioinert $[28,29]$. As explained above one of the most important applications of PEEK is for orthopedic area. The bioinert properties of PEEK in the orthopedic area mean the growth of soft tissues around the PEEK implant instead of bone growth (Figure 1) [30].

By changing the surface energy of the polymer, the reactions of the surrounded tissue to the polymeric implant can be improved, which could broaden its applications in the medical field, where direct bone interaction is important. Many methods have been used to alter the surface energy, and these methods can be broadly divided into two groups: compounding PEEK with a bioactive material and producing a composite and through surface modification. Figure 2 shows the general categorization of the existing methods for improving the bioactivity of PEEK.

\section{Surface Modification of PEEK's Implant}

Surface modification is a series of approaches which alter the properties of the surface of the material but do not affect the bulk properties of the material. Surface modification methods can be broadly divided into two broad categories: direct surface modification and deposition methods.

3.1. Direct Surface Modification. Direct surface modification methods are techniques that changed the surface properties of the material without depositing any layer of new material on the surface. These techniques consist of the following.

3.1.1. Wet Chemical Treatments. This is a method which is based on changing the surface chemistry of the implant and affects the bioactivity of the surface. Several studies reported that the bioactivity of PEEK could be increased by wet chemical treatment. Various chemical treatments modifying PEEK surface chemistry to PEEK-ONa, PEEK-OH, PEEK-F, and $\mathrm{PEEK}-\mathrm{OH}\left(\mathrm{CFCl}_{3}\right)$ showed a decrease in water contact angle of the implant and, therefore, increase the bioactivity of PEEK [31]. Another study showed that the amine and carboxyl functional group on the surface of PEEK could improve cellular adhesion and growth [28].

In vitro study on Fibronectin (FN) adsorption for probing the bioactivity of PEEK-OH, PEEK-NH $\mathrm{N}_{2}$, and PEEKNCO produced by wet chemical treatment showed protein can merely be adsorbed onto PEEK-NCO that Fibronectin covalently grafted to PEEK-NCO [32]. The performances of the FN-grafted substrate improved adhesion and spreading of Caco-2 cells in the absence of serum in comparison with PEEK substrates, which were simply coated with FN [33]. In another study, wet chemical treatment was used as a pretreatment for enhancement of apatite formation via immersion in SBF. The effect of $\mathrm{NaOH}$ pretreatments on apatite formation of PEEK in SBF showed the growth of apatite coating layer was enhanced with $\mathrm{NaOH}$ pretreatment [34].

A recent study probed the effect of sulphonation and the production of $3 \mathrm{D}$ porous and nanostructured network on in vitro cellular behavior and in vivo osseointegration and apatite formation. Two types of sulphonated PEEK (SPEEK) samples, SPEEK-W (sulphonated PEEK with just subsequent water immersion) and SPEEK-WA (SPEEK-W with additional acetone immersion) were probed. They showed new bone can grow and penetrate the porous sulphonated layer. The SPEEK-WA samples showed better cytocompatibility, bioactivity, osseointegration, and bone-implant bonding strength [22]. Table 1 presents the summary of the existing functional groups which have been deposited on PEEK via wet chemical deposition to enhance the bioactivity of it.

3.1.2. Plasma Surface Treatment. Plasma is often known as the fourth state of matter in which the gases are ionized and electrons are separated from their atoms. There are two types of plasma, hot plasma and cold plasma. In hot plasma using very high temperature, the gas is ionized. In cold plasma, the gas is ionized using low pressure in ambient temperature. The plasma can be used for altering the surface chemistry of the material. Plasma treatment of PEEK in oxygen, air, nitrogen, ammonia, and argon showed increasing of the wettability $[35,36]$.

In vitro study with osteoblast cells and wettability study carried out on plasma treated PEEK in $\mathrm{N}_{2} / \mathrm{O}_{2}$ showed the plasma treatment of PEEK reduced the water contact angle. In vitro study with osteoblast cells showed the plasma treatment does not have disadvantages on cell viability [37]. Plasma treated PEEK in $\mathrm{NH}_{3}$ showed lower water contact angle and 


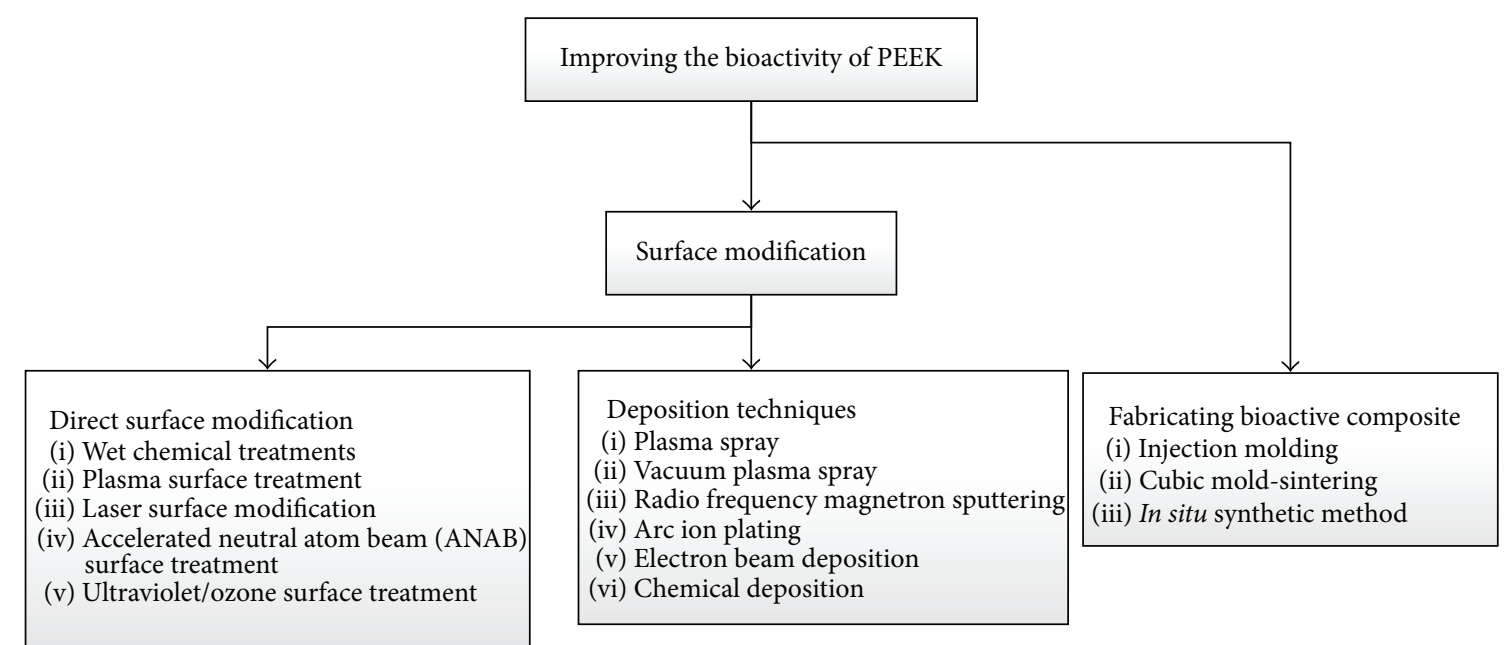

FIGURE 2: General categorization of the techniques for improving PEEK's bioactivity.

TABle 1: Deposited functional groups on PEEK via wet chemical deposition.

\begin{tabular}{|c|c|}
\hline $\begin{array}{l}\text { Functional } \\
\text { group }\end{array}$ & Results \\
\hline$-\mathrm{ONa}$ & $\begin{array}{l}\text { Enhancement of wettability [31]. } \\
\text { Enhancement of apatite formation [34]. }\end{array}$ \\
\hline$-\mathrm{OH}$ & $\begin{array}{l}\text { Enhancement of wettability [31]. } \\
\text { Disable to graft to Fibronectin [32]. }\end{array}$ \\
\hline$-\mathrm{F}$ & Enhancement of wettability [31]. \\
\hline$-\mathrm{OH}\left(\mathrm{CFCl}_{3}\right)$ & Enhancement of wettability [31]. \\
\hline Amine & $\begin{array}{l}\text { Improvement of cellular adhesion and growth } \\
{[28] \text {. }}\end{array}$ \\
\hline Carboxyl & $\begin{array}{l}\text { Improvement of cellular adhesion and growth } \\
{[28] \text {. }}\end{array}$ \\
\hline$-\mathrm{NH}_{2}$ & Disable to graft to Fibronectin [32]. \\
\hline$-\mathrm{NCO}$ & $\begin{array}{l}\text { Fibronectin covalently grafted to PEEK-NCO } \\
{[32] .}\end{array}$ \\
\hline $\begin{array}{l}\text { Fibronectin } \\
\text { grafting }\end{array}$ & $\begin{array}{l}\text { Enhancement of adhesion and spreading of } \\
\text { Caco- } 2 \text { cells in the absence of serum in } \\
\text { comparison with PEEK substrates, which were } \\
\text { simply coated with FN [33]. }\end{array}$ \\
\hline$-\mathrm{SO}_{3} \mathrm{H}$ & $\begin{array}{l}\text { Producing 3D nanostructured treated layer. } \\
\text { In vitro (cell culture and apatite formation) and } \\
\text { in vivo study showed enhancement of } \\
\text { bioactivity [22]. }\end{array}$ \\
\hline
\end{tabular}

increased cell growth [38]. Osteoblast biocompatibility test showed required biocompatibility for plasma treated PEEK in ammonia/argon and hydrogen/argon. Higher rate of cell proliferation and lower contact angle were demonstrated for plasma treated PEEK in comparison with untreated PEEK [39]. Plasma treatment of PEEK in chamber of $\mathrm{CH}_{4} / \mathrm{O}_{2}$ gas mixture showed better cell adhesion and lower water contact angle [40]. In vivo study of oxygen plasma, modified PEEK in cortical and cancellous bone of the sheep showed an increase in push-out force test and the percentage of the bone-implant contact area in comparison of untreated PEEK [41]. In vitro study via osteoblast precursor cells MC3T3-E1 and rat bone mesenchymal stem cells on plasma immersion ion implantation treatment with a gas mixture of water vapor as a plasma resource and argon as an ionization assistant of PEEK showed improvement of osteoblast adhesion, spreading, proliferation, and early osteogenic differentiation [42]. Also tuned PEEK by argon plasma treatment showed increasing of the surface roughness in comparison with pristine PEEK. As a consequence due to higher surface roughness and changing the surface chemistry of the treated PEEK, significant enhancements in terms of cell adhesion, proliferation, and metabolic activity were observed when compared to pristine PEEK [43]. Probing the effect of plasma treatment of PEEK by $\mathrm{O}_{2} / \mathrm{Ar}$ or $\mathrm{NH}_{4}$ on adhesion, proliferation, and osteogenic differentiation of adipose tissue-derived mesenchymal stem cells (adMSC) showed an improvement of bioactivity of plasma treated samples in comparison with nontreated samples [44]. Table 2 summarizes the ionization assistants which have been used for enhancement of the bioactivity of PEEK via plasma surface treatment method.

3.1.3. Laser Surface Modification. Laser is a high energy photon source which can alter the surface roughness and wettability of the polymers. Laser treatments are used due to their low cost, high resolution, high-operating speed, and the fact that lasers do not change the bulk properties of implant. For these reasons, lasers become very interesting for scientists in order to improve the surface energy of the implants [45, 46]. This surface treatment technique can modify the surface chemistry of PEEK $[47,48]$. Investigation into the effect of laser wavelengths on the wettability of PEEK showed the capability of this method in increasing the wettability of the PEEK for biomedical applications [49].

3.1.4. Accelerated Neutral Atom Beam (ANAB) Surface Treatment. This technique is a method which is used to enhance the bioactivity of PEEK and improve the bone-implant 
TABLE 2: Different ionization assistants which have been used for improving the bioactivity of PEEK via plasma treatment.

\begin{tabular}{ll}
\hline Ionization assistant & Results \\
\hline Oxygen & $\begin{array}{l}\text { Enhancement of wettability [35, 36]. } \\
\text { Increase of push-out force and bone-implant } \\
\text { contact area [41]. }\end{array}$ \\
\hline Air & Enhancement of wettability [35, 36]. \\
\hline Nitrogen & Enhancement of wettability [35, 36]. \\
\hline Ammonia & Enhancement of wettability [35, 36]. \\
\hline Argon & $\begin{array}{l}\text { Enhancement of wettability [35, 36]. } \\
\text { Using vapor as a plasma resource showed } \\
\text { improvement of osteoblast adhesion, } \\
\text { spreading, proliferation, and early } \\
\text { osteogenic differentiation [42]. } \\
\text { Increasing surface roughness, enhancement } \\
\text { of cell adhesion, proliferation, and metabolic } \\
\text { activity [43]. }\end{array}$ \\
\hline $\mathrm{N}_{2} / \mathrm{O}_{2}$ & $\begin{array}{l}\text { In vitro study via osteoblast cells showed no } \\
\text { disadvantages on cell viability [37]. }\end{array}$ \\
\hline $\mathrm{NH}_{3}$ & $\begin{array}{l}\text { Enhancement of wettability and increasing } \\
\text { cell growth [38]. }\end{array}$ \\
\hline $\mathrm{Ammonia}_{2} / \mathrm{argon}$ & $\begin{array}{l}\text { Enhancement of cell proliferation rate and } \\
\text { enhancement of wettability [39]. }\end{array}$ \\
\hline $\mathrm{Hydr}_{4} / \mathrm{O}_{2}$ & $\begin{array}{l}\text { Enhancement of cell proliferation rate and } \\
\text { enhancement of wettability [39]. }\end{array}$ \\
\hline $\begin{array}{l}\text { Enhancement of cell adhesion and } \\
\text { enhancement of wettability [40]. }\end{array}$ \\
$\begin{array}{l}\text { Enhancement of cell adhesion, proliferation, } \\
\text { and osteogenic differentiation of adMSC } \\
{[40] .}\end{array}$ \\
$\begin{array}{l}\text { Enhancement of cell adhesion, proliferation, } \\
\text { and osteogenic differentiation of adMSC } \\
{[40] .}\end{array}$ \\
\hline
\end{tabular}

integrity. In this technique a powerful beam of cluster-like packets of accelerated unbonded neutral argon (Ar) gas atoms is used to modify the surface of PEEK. The results showed that ANAB treatment of PEEK modified the surface in the nanometer scale, increased surface wettability, and improved human osteoblast cell proliferation to a level comparable with titanium. The in vivo study shows the bone tissue formation on the ANAB treated PEEK while no growth of bone tissue on the untreated PEEK was observed [50]. The atomic force microscope examination showed the effect of $A N A B$ technique in producing nanoscale texturing on the surface. In vitro study of ANAB treated PEEK showed better osteoblast cell adhesion in comparison with untreated PEEK [51].

3.1.5. Ultraviolet/Ozone Surface Treatment. Polymers can be degraded by exposure to sunlight because of the chemical reaction activation due to short wavelengths of ultraviolet (UV) of sunlight and photon-activation cross-linking or fragmentation of the polymer. UV/ozone treatment method for PEEK was used to change the surface energy of PEEK. The results showed increasing of the surface wettability of the treated PEEK by UV/ozone [52].
3.2. Deposition Techniques. Several methods exist for depositing bioactive material on PEEK such as plasma spraying, vacuum deposition, sol gel, dip coating, and immersion in SBF method [53]. In this section, the trend of progress of PEEK's coating is described based on the coated materials.

Hydroxyapatite is one of the most important materials which have been used widely for coating of biomaterials. HA coating on carbon fiber reinforced PEEK (CF/PEEK) via plasma spray method showed low adhesion of the coating layer to the substrate [54]. The authors explained that the high temperature used in plasma spray method caused the evaporation of the PEEK substrate preventing close contact between coating layer and substrate. In the next study, they coated titanium intermediate layer via vacuumplasma-sprayed and after that coated hydroxyapatite layer on $\mathrm{CF} / \mathrm{PEEK}$ for increasing the adhesion between the coating layer and the substrate. The cross section study showed very good interlocking between the PEEK substrate and the intermediate Ti layer [55]. To prevent damage to the PEEK substrate due to the high temperature during the coating process and damage to the PEEK substrate during the sintering, intermediate coating layer of yttria-stabilized zirconia (YSZ) was first deposited onto PEEK and after that the HA coating layer was deposited via radio frequency magnetron sputtering method. For increasing the adhesion between the substrate and coating layer, preplasma treatment was used for substrate. Microwave was used for sintering and forming crystalline HA coating layer. The authors showed the crystalline YSZ layer encouraged the HA layer during the sintering procedure by providing nucleation site for HA grain formation [56]. Hydroxyapatite coating via plasma spraying method on different PEEK (unfilled and carbon fiber reinforced composite) specimens was studied and chemical, crystallographic compositions, adhesions, and microstructures of HA coating via plasma spraying method on different PEEK (unfilled and CF/PEEK) specimens and comparison with HA coating on Ti- $6 \mathrm{Al}-4 \mathrm{~V}$ showed almost the same structure of HA coatings for PEEK and Ti-6Al-4V substrate. Mechanical tests showed the plasma spraying method does not have a negative effect on mechanical properties of PEEK implant [57]. In vitro study with human bone marrow mesenchymal stem cells of HA coated PEEK via cold spray method showed early cell adhesion, viability improvement, and increased cell differentiation and proliferation. In vivo study on rabbits showed promotion of bone growth and integrity with the implant after coating [58]. HA coating on medical-grade PEEK via aerosol deposition showed dense microstructure with no pores and cracks with high-adhesion strength of HA coating layer without damaging the PEEK substrate. In vitro and in vivo study in terms of cell proliferation, differentiation, adhesion morphology, and bone-implant contact ratio showed enhancement for HA coated sample in comparison to uncoated PEEK [59]. In vivo osseointegration (histomorphometry) study of surface modified PEEK implants showed the nano-HA coated implants have more bone area and more bone-to-implant contact in comparison to uncoated PEEK [60]. In our recent study the HA crystalline particles were chemically deposited on the PEEK's surface whereby crystallization process and high temperature for deposition 
of the HA were eliminated. For depositing the HA particles, the surface of the PEEK was sulphonated first to establish the $-\mathrm{SO}_{3} \mathrm{H}$ functional group, and then the polarity property of the HA particles was used to attach the particles to the functional group. The surface treatment was able to decrease the water contact angle from 72 to 36.4 degrees [61]. In vitro study comprising apatite formation via SBF immersion and mesenchymal stem cell proliferation confirmed enhancement of bioactivity of treating PEEK via this method [62].

In vitro osteoblast study of PEEK substrate coated with $\mathrm{TiO}_{2}$ via arc ion plating method showed a significant improvement in cell adhesion, proliferation, and differentiation compared with an uncoated PEEK substrate [21]. The anatase-rich titanium dioxide $\left(\mathrm{A}-\mathrm{TiO}_{2}\right)$ and especially rutile-rich titanium dioxide $\left(\mathrm{R}-\mathrm{TiO}_{2}\right)$ intermediate layer onto the PEEK substrate showed enhancement of produced HA layer after immersion in SBF in comparison with pure PEEK. The authors explained that the intermediate layer, by providing nucleation site for growing HA, improves the produced HA layer. Osteocompatibility evaluation showed the produced HA layer improves osteocompatibility, in which $\mathrm{R}-\mathrm{TiO}_{2}$ achieves the best result [63]. In another study the bone morphogenetic protein-2 (BMP-2) was immobilized on porous $\mathrm{TiO}_{2}$ coating layer on PEEK. The bone-to-implant contact ratio study showed better interaction of $\mathrm{TiO}_{2} / \mathrm{BMP}-2$ coating layer in comparison with $\mathrm{TiO}_{2}$, and BMP-2 coating layer and pure PEEK [64].

In vivo study on sheep was performed on titanium plasma spray coating on the PEEK screw. Histological investigation showed higher bone-to-implant contact and lower soft tissue around coated samples in comparison with pure PEEK [65]. Electron beam deposition of $\mathrm{Ti}$ on PEEK produced a dense coating layer at low temperature. In vitro study in terms of proliferation and differentiation of MC3T3-E1 cells showed more than double improvement after Ti coating in comparison with pure PEEK. In vivo study showed that the bone-to-implant contact ratio increased with coating Ti on the PEEK substrate [6]. In another study the vacuum-plasmasprayed Ti coating layer on CF/PEEK substrate was treated by sodium hydroxide $(\mathrm{NaOH})$ solution for improving its bioactivity. In vitro study via SBF showed apatite formation on the coated samples while no apatite was formed on the untreated PEEK samples [66]. In vivo comparative study for probing the effect of two different methods of PVD and VPS for deposition of the Ti on CF/PEEK screws showed no significant difference between these two methods in terms of bioactivity. The coated screws by these two methods showed better bone deposition and higher removal torque in comparison with uncoated screws [67].

An in vivo study of Ti-coated CF/PEEK for dental implant application via plasma vapor deposition was carried out to evaluate the bioactivity of Ti-coated CF/PEEK. The results showed direct growth of new bone for both coated and uncoated PEEK samples, but the coated samples showed better bone growth around the coated implant. However, the push-out test revealed almost the same interface strength between the coated and uncoated samples by new bone growth [68]. In another study, electron beam deposition method was used to deposit pure titanium on PEEK. The
Ti coating layer showed superb adhesion properties to the PEEK substrate. Contact angle analysis showed the Ti coating enhances the wettability of PEEK. In vitro study by MC3T3E1 cells for methoxyphenyl tetrazolium salt (MTS) assay to measure the proliferation of the cells shows enhancement of more than double for coated samples. Alkaline phosphatase (ALP) assay showed double differentiation level of cells for Ticoated samples. Furthermore, an in vivo animal study showed much higher bone-in-contact (BIC) ratio for Ti-coated PEEK samples in comparison with the pure PEEK samples [6].

Zirconium and titanium tetra(tert-butoxides) are another bioactive material which was deposited on the surface PEEK at room temperature via vapor deposition to enhance the bioactivity of PEEK. The deposited metal layer reacted with the phosphonic acid for attachment of monolayer phosphonates. In vitro study showed significant enhancement of osteoblast cell growth as compared to the untreated surface [69]. Diamond-like carbon (DLC) is another material which was used to coat PEEK implant for increasing bioactivity. In vitro study via osteoblast showed better attachment, proliferation, and differentiation on DLC-coated PEEK compared to uncoated PEEK [70]. Table 3 presents the summary of the existing deposition methods/materials which have been used for enhancement of PEEK bioactivity.

\section{Bioactive PEEK Composites}

As explained before compounding with bioactive material is one strategy to increase the bioactivity of the PEEK implants. Different bioactive material such as HA, strontiumcontaining hydroxyapatite, $\mathrm{TiO}_{2}, \beta \mathrm{TCP}$, and bioactive glass was compounded with PEEK for increasing the bioactivity of PEEK's implant. PEEK composites were produced for different applications. The most important application is load bearing implant application [71], but several other studies were carried out to show the feasibility of producing threedimensional porous scaffold PEEK/HA for tissue engineering application [72-74] and cervical spinal fusion cages [75]. One of the most significant disadvantages of the PEEK composites is the low mechanical properties in comparison with PEEK [76-78]. Thus previous studies focused on probing the effect of different parameters on two important aspects of mechanical properties and bioactivity. In this part, previous studies of the PEEK composites were first broadly categorized as bioactivity and mechanical properties study, and in each category the trend of progress of PEEK's composites is described based on the compound material.

4.1. In Vitro and In Vivo Bioactivity Study of PEEK Composite. Several studies have been conducted to probe the effect of compounding PEEK with bioactive materials on in vitro and in vivo bioactivity of the produced composite. PEEK/HA composites with different volume fraction of HA up to 40 vol\% via injection molding method were evaluated in vivo. Preliminary histological in vivo study of composite with $20 \mathrm{vol} \%$ of HA showed the enhancement of the presence of fibroblast cells which stimulate vascularization. Osteoblastic 
TABLE 3: Summary of the existing deposition methods/materials for improving PEEK bioactivity.

\begin{tabular}{|c|c|c|c|}
\hline $\begin{array}{l}\text { Deposited } \\
\text { material }\end{array}$ & $\begin{array}{l}\text { Deposition } \\
\text { method }\end{array}$ & Area of studies & Findings \\
\hline \multirow{8}{*}{ HA } & Plasma spray & - & $\begin{array}{l}\text { Low adhesion of the coating layer to the substrate } \\
\text { [54]. }\end{array}$ \\
\hline & $\begin{array}{l}\text { Vacuum- } \\
\text { plasma-sprayed }\end{array}$ & Using titanium intermediate coating layer & $\begin{array}{l}\text { Good interlocking between PEEK substrate and } \\
\text { intermediate Ti layer and preventing damage of } \\
\text { the substrate [55]. }\end{array}$ \\
\hline & $\begin{array}{l}\text { Radio frequency } \\
\text { magnetron } \\
\text { sputtering }\end{array}$ & $\begin{array}{l}\text { Crystalline YSZ layer was deposited as an } \\
\text { intermediate layer }\end{array}$ & $\begin{array}{l}\text { Enhancement crystallinity of HA deposited layer } \\
\text { during sintering [56]. }\end{array}$ \\
\hline & Plasma spraying & $\begin{array}{l}\text { Crystallographic compositions, adhesions, and } \\
\text { microstructures of HA coating via plasma spraying } \\
\text { method on different PEEK (unfilled and CF/PEEK) } \\
\text { specimens were studied and compared with HA } \\
\text { coating on Ti- } 6 \mathrm{Al}-4 \mathrm{~V}\end{array}$ & $\begin{array}{l}\text { Almost the same structure of HA coatings for } \\
\text { PEEK and Ti-6Al-4V substrate. Plasma spraying } \\
\text { method does not have a negative effect on } \\
\text { mechanical properties of PEEK [57]. }\end{array}$ \\
\hline & $\begin{array}{l}\text { Vacuum- } \\
\text { plasma-sprayed }\end{array}$ & $\begin{array}{l}\text { In vitro study with human bone marrow } \\
\text { mesenchymal stem cells and in vivo study }\end{array}$ & $\begin{array}{l}\text { Viability improvement and enhancement of cell } \\
\text { differentiation and proliferation. Promoting of } \\
\text { bone growth [58]. }\end{array}$ \\
\hline & $\begin{array}{l}\text { Aerosol } \\
\text { deposition }\end{array}$ & Microstructure, in vivo, in vitro study & $\begin{array}{l}\text { Dense microstructure with no pores and cracks. } \\
\text { Enhancement of bioactivity in terms of cell } \\
\text { proliferation, differentiation, adhesion } \\
\text { morphology, and bone-implant contact ratio [59]. }\end{array}$ \\
\hline & Spin coating & In vivo osseointegration (histomorphometry) study & $\begin{array}{l}\text { Improvement of bone-to-implant contact area } \\
{[60] .}\end{array}$ \\
\hline & $\begin{array}{l}\text { Chemical } \\
\text { deposition }\end{array}$ & $\begin{array}{l}-\mathrm{SO}_{3} \mathrm{H} \text { functional group was created via } \\
\text { sulphonation and HA crystalline particles were } \\
\text { chemically deposited }\end{array}$ & $\begin{array}{l}\text { The proposed method did not use high } \\
\text { temperature and improved the wettability [61]. }\end{array}$ \\
\hline $\begin{array}{l}\mathrm{A}-\mathrm{TiO}_{2} \text { and } \\
\mathrm{R}-\mathrm{TiO}_{2}\end{array}$ & Arc ion plating & In vitro $\mathrm{SBF}$ immersion and osteocompatibility study & $\begin{array}{l}\text { Enhancement of apatite formation and } \\
\text { improvement of osteocompatibility, in which } \\
\mathrm{R}-\mathrm{TiO}_{2} \text { achieves the best result [63]. }\end{array}$ \\
\hline $\mathrm{TiO}_{2}$ & Arc ion plating & In vitro osteoblast study & $\begin{array}{l}\text { Improvement in cell adhesion, proliferation, and } \\
\text { differentiation [21]. }\end{array}$ \\
\hline $\mathrm{TiO}_{2} / \mathrm{BMP}-2$ & Immobilization & In vivo study & $\begin{array}{l}\text { Enhancement of bone-to-implant contact ratio in } \\
\text { comparison with } \mathrm{TiO}_{2} \text { and BMP-2 coating layer } \\
\text { and bare PEEK [64]. }\end{array}$ \\
\hline \multirow{6}{*}{$\mathrm{Ti}$} & Plasma spray & In vivo study & Enhancement bone-to-implant contact ratio [65]. \\
\hline & $\begin{array}{l}\text { Electron beam } \\
\text { deposition }\end{array}$ & $\begin{array}{l}\text { In vitro study in terms of proliferation and } \\
\text { differentiation of MC3T3-E1 cells and in vivo study }\end{array}$ & $\begin{array}{l}\text { Enhancement of in vitro bioactivity and } \\
\text { bone-to-implant contact ratio [6]. }\end{array}$ \\
\hline & VPS & $\begin{array}{l}\text { Probing the effect of pretreatment of the substrate } \\
\text { with } \mathrm{NaOH} \text { solution on bioactivity via in vitro SBF } \\
\text { immersion study }\end{array}$ & $\begin{array}{l}\text { Improvement bioactivity in terms of apatite } \\
\text { formation [66]. }\end{array}$ \\
\hline & PVD and VPS & $\begin{array}{l}\text { In vivo comparative study for probing the effect of } \\
\text { PVD and VPS methods on the Ti deposited on } \\
\text { CF/PEEK substrate }\end{array}$ & $\begin{array}{l}\text { No significant difference between these two } \\
\text { methods in terms of bioactivity [67]. }\end{array}$ \\
\hline & PVD & $\begin{array}{l}\text { In vivo study of Ti-coated CF/PEEK for dental } \\
\text { implant application }\end{array}$ & $\begin{array}{l}\text { Coated samples showed better bone growth } \\
\text { around the coated implant but the same push-out } \\
\text { force for coated and uncoated samples by new } \\
\text { bone growth [68]. }\end{array}$ \\
\hline & $\begin{array}{l}\text { Electron beam } \\
\text { deposition }\end{array}$ & $\begin{array}{l}\text { Wettability, in vitro study via MC3T3-E1 cell and in } \\
\text { vivo study }\end{array}$ & $\begin{array}{l}\text { Enhancement of in vitro bioactivity and } \\
\text { bone-in-contact ratio [6]. }\end{array}$ \\
\hline $\begin{array}{l}\text { Zirconium } \\
\text { and titanium } \\
\text { tetra }\end{array}$ & PVD & In vitro study via osteoblast & Enhancement of osteoblast cell growth [69]. \\
\hline DLC & $\begin{array}{l}\text { Plasma } \\
\text { immersion ion } \\
\text { implantation } \\
\text { and deposition }\end{array}$ & In vitro study via osteoblast & $\begin{array}{l}\text { Enhancement of attachment, proliferation, and } \\
\text { differentiation of osteoblast [70]. }\end{array}$ \\
\hline
\end{tabular}


activities study showed the formation of osteoid and osteocytes within lamellar bone in developing mature bone at longer implantation periods [15]. The SBF bioactivity test on HA/PEEK composites with different volume fraction up to $40 \%$ which were prepared by mixing of $\mathrm{HA}$ and PEEK powders, compaction, and sintering showed the higher rate of HA growth for the composite with higher volume fraction percentage of HA [14]. Biological study of HA/PEEK composites which were prepared by mixing and sintering the material powders using simple cubic mold shows the capability of this technique to replace the injection molding which is a high-cost method. In vitro study via SBF and cell seeding tests confirmed the bioactivity of the composite [79]. For better dispersion of HA particles in HA/PEEK composite nanosized HA (nHA)/PEEK with different nHA contents $(15.1,21.6,29.2$, and 38.2 vol\%) was fabricated by $\mathrm{Li}$ et al. [80]. In vitro study via SBF immersion, cell adhesion, and proliferation showed nanocomposite with $29.2 \mathrm{vol} \%$ of nHA content has the best bioactivity in comparison with other samples. For the improvement, the bonding between HA and PEEK of the HA/PEEK composite was fabricated via in situ synthetic method [81-83]. The biocompatibility study of in situ synthetic method for fabrication of composite showed the fabricated composites are nontoxic, and the bioactivity study showed the produced composites are bioactive.

Study of the bioactivity of $\beta$ TCP-PEEK composite via injection molding method showed lower rates of osteoblast growth on the $\beta$ TCP-PEEK compared to pure PEEK [84]. In vitro study with osteoblast cells confirmed the nontoxicity of laser sintering method for producing $\beta \mathrm{TCP} / \mathrm{PEEK}$ composite but showed no advantage of adding $\beta$ TCP as fillers on cell growth $[85,86]$. However, in vivo study of the laser sintered PEEK/ $\beta$ TCP implant revealed the PEEK/ $\beta$ TCP implants showed better interaction with surrounding bone and direct connection to the surrounding bone in comparison with pure PEEK [87].

In vitro study with osteoblast cells confirms the nontoxicity of laser sintering method for producing carbon black/PEEK composite but showed no advantage of adding carbon black as fillers on cell growth [85]. In vitro study of HA/PEEK composite via selective laser sintering method showed improvement in bioactivity of the composite in comparison with pure PEEK. The results showed higher content of HA exhibited enhancement in cell proliferation and osteogenic differentiation [88].

In vitro osteoblast cell proliferation and viability study from PEEK, PEEK/carbon, PEEK/carbon/ $\beta$ TCP, and PEEK/ carbon/bioglass 4s5S5 composites via laser sintering method revealed that all samples were nontoxic. However, the cell culture test did not show any advantageous effect of $\beta$ TCP in the PEEK composite on the bioactivity properties of the samples. High-proliferation rates of osteoblasts on PEEK/carbon/bioglass composite showed the significant effect of bioglass on improving the bioactivity of the composite [86]. In vitro study via MG-63 cells on glass fiber/PEEK composite showed a higher rate of cell proliferation on the surface of the composite compared to pure PEEK $[89,90]$.
Nano- $-\mathrm{TiO}_{2}$ is another additive which is used for improvement in the bioactivity of PEEK composite. In vitro and vivo studies confirmed the positive effect of nano- $\mathrm{TiO}_{2}$ on improvement of bioactivity of PEEK. In vitro study demonstrated that compounding PEEK with nano- $\mathrm{TiO}_{2}$ was able to increase cell attachment and enhanced osteoblast cell spreading. In in vivo studies, the enhancement of the bone regeneration around the nano- $\mathrm{TiO}_{2} / \mathrm{PEEK}$ composite implant was observed by higher bone volume/tissue volume in comparison with the PEEK implant [20].

In another study of increasing the bioactivity of PEEK, strontium-containing hydroxyapatite/polyether ketone (SrHA/PEEK) composites were fabricated by compression molding technique. In vitro study involving apatite formation in SBF and MG-63-mediated mineralization confirmed higher bioactivity in comparison to HA/PEEK composite [16]. Also, calcium oxide and silicon dioxide (CS) were used as bioactive additives to PEEK composite. In vitro bioactivity study via SBF showed that by increasing the volume fraction of CS the bioactivity of the composite increased [91]. Table 4 summarizes the effect of the compound materials on the enhancement of the bioactivity of the PEEK composites.

4.2. Mechanical Properties of PEEK Composite. PEEK exhibits superb mechanical properties appropriate for load bearing orthopedic applications. However, as mentioned before the low mechanical properties of bioactive PEEK composites in comparison to PEEK are one of the biggest concerns of scientists and a lot of works in this field have been done. In this part, the present works based on the additives are described.

Studies showed that increasing the volume fraction of $\mathrm{HA}$ in the HA/PEEK composite increased Young's modulus and microhardness of the composite, though strength and strain at the fracture point decreased [76]. However, cyclic load on the PEEK/HA composite with different content of HA showed the HA/PEEK composite is a promising fatigue-resistant material for biomedical applications [92]. For improving the mechanical properties of the HA/PEEK composites the composites were prepared via in situ process. The composite showed strong physical bonding between $\mathrm{HA}$ and PEEK matrix due to improvement of mechanical properties of the composite in comparison with previously prepared HA/PEEK composites by other methods [81-83].

The mechanical properties of PEEK/HA nanoparticle composite showed the initial increase of tensile strength by increasing the content of HA nanoparticles to $5 \mathrm{vol} \%$ and after that decreasing the tensile strength. The authors described the first increase in tensile strength that was due to the "strong interactivity of nanoparticles and PEEK chains," and they explained the agglomeration of HA nanoparticles for the contents of over $10 \mathrm{vol} \%$ which was due to decreased binding between nanoparticles and $\mathrm{PEEK}$ and reduction in the tensile strength of the composite $[77,78]$.

PEEK/HA whiskers composite via compression molding method showed the additive HA whiskers were oriented in the direction of viscous flow due to the production of composites with anisotropy mechanical properties. The results 
TABLE 4: Effect of the compound materials on the bioactivity of the PEEK composite.

\begin{tabular}{|c|c|c|}
\hline $\begin{array}{l}\text { Compound } \\
\text { material }\end{array}$ & Studied areas & Results \\
\hline \multirow{5}{*}{ HA } & $\begin{array}{l}\text { Probing the effect of HA volume fraction on bioactivity } \\
\text { via in vivo study. }\end{array}$ & $\begin{array}{l}\text { Enhancement of the presence of fibroblast cells, } \\
\text { formation of osteoid and osteocytes within lamellar } \\
\text { bone [15]. }\end{array}$ \\
\hline & $\begin{array}{l}\text { Probing the effect of HA volume fraction on bioactivity } \\
\text { via SBF immersion test. }\end{array}$ & $\begin{array}{l}\text { Higher rate of HA growth for the composite with } \\
\text { higher volume fraction of HA [14]. }\end{array}$ \\
\hline & $\begin{array}{l}\text { In vitro study of the new method of simple cubic } \\
\text { molding and sintering. }\end{array}$ & $\begin{array}{l}\text { Confirmed improvement of bioactivity of the } \\
\text { composite [79]. }\end{array}$ \\
\hline & $\begin{array}{l}\text { Biocompatibility and bioactivity study of the produced } \\
\text { composite via in situ synthetic method. }\end{array}$ & $\begin{array}{l}\text { Produced composite showed nontoxic and the bioactive } \\
\text { properties [81-83]. }\end{array}$ \\
\hline & $\begin{array}{l}\text { In vitro bioactivity study of HA/PEEK composite } \\
\text { produced by selective laser sintering method. }\end{array}$ & $\begin{array}{l}\text { Improvement in bioactivity of the composite and higher } \\
\text { content of HA exhibited higher bioactivity rate [88]. }\end{array}$ \\
\hline nHA & $\begin{array}{l}\text { Probing the effect of nHA volume fraction on } \\
\text { bioactivity via in vitro study by SBF immersion, cell } \\
\text { adhesion, and proliferation. }\end{array}$ & $\begin{array}{l}\text { Nanocomposite with } 29.2 \text { vol\% of nHA content showed } \\
\text { the best bioactivity in comparison with other samples } \\
{[80] .}\end{array}$ \\
\hline \multirow{3}{*}{$\beta$ TCP } & In vitro bioactivity study via osteoblast cells. & $\begin{array}{l}\text { Lower rates of osteoblast growth on the } \beta \text { TCP-PEEK } \\
\text { compared to pure PEEK [84]. }\end{array}$ \\
\hline & $\begin{array}{l}\text { Biocompatibility study of laser sintering method for } \\
\text { producing } \beta \text { TCP/PEEK via in vitro study by osteoblast } \\
\text { cells. }\end{array}$ & $\begin{array}{l}\text { Confirmed nontoxicity of laser sintering method for } \\
\text { producing } \beta \text { TCP/PEEK composite but showed no } \\
\text { advantage of adding } \beta \text { TCP as an additive on cell growth } \\
{[85,86] \text {. }}\end{array}$ \\
\hline & $\begin{array}{l}\text { In vivo bioactivity study of the laser sintered } \\
\text { PEEK/ } \beta \text { TCP composite. }\end{array}$ & $\begin{array}{l}\text { Better interaction with surrounding bone and direct } \\
\text { connection to the surrounding bone [87]. }\end{array}$ \\
\hline Carbon black & $\begin{array}{l}\text { Biocompatibility study of laser sintering method for } \\
\text { producing carbon black/PEEK composite via in vitro } \\
\text { study by osteoblast cells. }\end{array}$ & $\begin{array}{l}\text { Confirmed nontoxicity of laser sintering method for } \\
\text { producing carbon black/PEEK composite but showed } \\
\text { no advantage of adding carbon black as an additive on } \\
\text { cell growth [85]. }\end{array}$ \\
\hline $\begin{array}{l}\text { Carbon, } \\
\text { carbon/ } \beta \mathrm{TCP}, \text { and } \\
\text { carbon/bioglass } \\
4 \text { s5S5 }\end{array}$ & $\begin{array}{l}\text { Biocompatibility and bioactivity study of produced } \\
\text { composites via laser sintering method. }\end{array}$ & $\begin{array}{l}\text { Produced composite via laser sintering method was } \\
\text { nontoxic. PEEK/carbon/bioglass composite showed } \\
\text { improvement in the bioactivity property [86]. }\end{array}$ \\
\hline Glass fiber & In vitro study via MG-63 cells. & Higher rate of cell proliferation $[89,90]$. \\
\hline Nano- $\mathrm{TiO}_{2}$ & In vitro and in vivo study. & $\begin{array}{l}\text { Increasing in cell attachment and enhanced osteoblast } \\
\text { cell spreading. Enhancement of the bone regeneration } \\
\text { around the nano- } \mathrm{TiO}_{2} / \text { PEEK composite }[20] \text {. }\end{array}$ \\
\hline Sr-HA & $\begin{array}{l}\text { In vitro study contains apatite formation in SBF and } \\
\text { MG-63-mediated mineralization. }\end{array}$ & Enhancement of bioactivity [16]. \\
\hline CS & $\begin{array}{l}\text { Probing the effect of CS volume fraction on bioactivity } \\
\text { via in vitro bioactivity study by SBF immersion. }\end{array}$ & $\begin{array}{l}\text { By increasing the volume fraction of CS the bioactivity } \\
\text { of the composite increased [91]. }\end{array}$ \\
\hline
\end{tabular}

of mechanical properties showed an increase in the volume fraction of HA whisker reinforcement due to increased elastic modulus of the composite but caused a decrease in the ultimate tensile strength/strain at the failure point [18].

Polyether ketone (PEKK) reinforced with 0, 20, and 40 vol\% HA whiskers specimens by compression molding method and subsequent annealing showed a decrease of the fatigue life with the increase in the volume fraction of the HA whiskers [93]. Effect of HA contents and mold temperature on the mechanical properties of PEKK/HA whiskers scaffolds was studied. The elastic modulus of the scaffold increased from 0 to $20 \mathrm{vol} \% \mathrm{HA}$ with the increase of $\mathrm{HA}$ value from 20 to $40 \mathrm{vol} \%$, while the yield strength and strain at the fracture point were decreased with increasing volume fraction of HA. Elastic modulus, yield strength, and yield strain were also increased by increasing the mold temperature [94].

The bending modulus of strontium-containing hydroxyapatite/polyether ketone (Sr-HA/PEEK) increased with increasing the volume fraction of $\mathrm{Sr}-\mathrm{HA}$. The elastic modulus of $25 \mathrm{vol} \%$ and $30 \mathrm{vol} \%$ Sr-HA reinforcement showed $113 \%$ and $136 \%$ increase, respectively, in comparison with pure PEEK. The bending strengths of $25 \mathrm{vol} \%$ and $30 \mathrm{vol} \% \mathrm{Sr}-\mathrm{HA}$ reinforcement showed $25 \%$ and $29 \%$ decrease, respectively, in comparison with pure PEEK [16]. Table 5 presents the summary of the effect of different compounds on the mechanical properties of the PEEK composite. 
TABLE 5: Effect of the compound materials on the mechanical properties of the PEEK composites.

\begin{tabular}{|c|c|c|}
\hline $\begin{array}{l}\text { Compound } \\
\text { material }\end{array}$ & $\begin{array}{l}\text { Studied mechanical } \\
\text { properties }\end{array}$ & Results \\
\hline \multirow{3}{*}{ HA } & $\begin{array}{l}\text { E, microhardness, } \\
\text { ultimate tensile } \\
\text { strength/strain }\end{array}$ & $\begin{array}{l}\text { Young's modulus and microhardness of composite increased, ultimate tensile strength and } \\
\text { strain at the fracture point decreased [76]. }\end{array}$ \\
\hline & Fatigue-resistant & Showing enough fatigue-resistant property for biomedical applications [92]. \\
\hline & Ultimate tensile strength & $\begin{array}{l}\text { Prepared composite via in situ process showed strong physical bonding between HA and } \\
\text { PEEK matrix and enhanced ultimate tensile strength [81-83]. }\end{array}$ \\
\hline HAnp & Ultimate tensile strength & $\begin{array}{l}\text { Initial increase of tensile strength by increasing HAnp content to } 5 \mathrm{vol} \% \text { and after that } \\
\text { decreasing the tensile strength }[77,78] \text {. }\end{array}$ \\
\hline \multirow{3}{*}{ Whiskers HA } & $\begin{array}{l}\text { E, isotropy property, } \\
\text { ultimate tensile } \\
\text { strength/strain }\end{array}$ & $\begin{array}{l}\text { Anisotropy mechanical properties, increasing of } \mathrm{E} \text { and decreasing in the ultimate tensile } \\
\text { strength/strain by increasing of the volume fraction of HA whisker reinforcement [18]. }\end{array}$ \\
\hline & Fatigue life & $\begin{array}{l}\text { Decreasing of the fatigue life with increase in the volume fraction of the HA whiskers in } \\
\text { PEKK [93]. }\end{array}$ \\
\hline & $\begin{array}{l}\text { E, ultimate strength and } \\
\text { strain }\end{array}$ & $\begin{array}{l}\text { Elastic modulus increased, while the ultimate tensile strength and strain decreased with } \\
\text { increasing volume fraction of HA. } \\
\text { Elastic modulus, yield strength, and yield strain were increased by increasing the mold } \\
\text { temperature [94]. }\end{array}$ \\
\hline Sr-HA & E, bending strength & $\begin{array}{l}\text { The bending modulus, elastic modulus increased with the volume fraction ratio of Sr-HA. } \\
\text { The elastic modulus of } 25 \text { vol\% and } 30 \text { vol\% Sr-HA reinforcement showed } 113 \% \text { and } 136 \% \\
\text { increase, respectively, in comparison with pure PEEK. The bending strengths of } 25 \text { vol\% and } \\
30 \text { vol\% Sr-HA reinforcement showed } 25 \% \text { and } 29 \% \text { decrease, respectively, in comparison } \\
\text { with pure PEEK [16]. }\end{array}$ \\
\hline
\end{tabular}

\section{Summary and Conclusion}

For long term load bearing implant applications, PEEK is the only commercial material that offers characteristics with good chemical resistance, radiolucency, and mechanical properties similar to those of human bones. However, bioactivity of PEEK is the biggest hindrance which causes reduction in the acceleration of worldwide spreading. We have summarized the previous study of bioactivation of PEEK and categorized them broadly to the bioactive PEEK composites and surface modified PEEK. The biggest concern about the PEEK composite is its mechanical properties. Thus, the PEEK bioactive composites were subcategorized to probe the previous studies from the bioactivity and mechanical aspects. Although different bioactive additives such as HA, $\mathrm{Ti}, \mathrm{TiO}_{2}, \beta$-tricalcium phosphate, and bioactive glass improve the bioactivity of PEEK's composite, the low mechanical properties of PEEK's composite are still its most important weakness. The surface modification of PEEK for biomedical application was subcategorized based on the techniques which were used for modifying the surface of the PEEK's implants. Between these methods the deposition of HA via plasma spraying method is the only method which qualified for commercial usage. However, there are still some concerns with this method such as damaging the surface chemistry of PEEK substrate and therefore in-depth research is needed. The trend of research in the bioactivity of PEEK shows a very encouraging result which has potential to overcome the existing problems in the current techniques and production of bioactive PEEK implant and spreading its application as bioactive material in orthopedic and dental implant areas.

\section{Competing Interests}

The authors declare that they have no competing interests.

\section{Acknowledgments}

The authors would like to acknowledge Universiti Teknologi Malaysia (UTM) for providing research facilities and financial support under grant of Potential Academic Staff with Grant no. Q.J130000.2745.01K62 and FRGS no. PY/2015/05371.

\section{References}

[1] S. M. Kurtz and J. N. Devine, "PEEK biomaterials in trauma, orthopedic, and spinal implants," Biomaterials, vol. 28, no. 32, pp. 4845-4869, 2007.

[2] D. Williams, "Polyetheretherketone for long-term implantable devices," Medical Device Technology, vol. 19, no. 1, pp. 8-11, 2008.

[3] J. M. Toth, M. Wang, B. T. Estes, J. L. Scifert, H. B. Seim III, and A. S. Turner, "Polyetheretherketone as a biomaterial for spinal applications," Biomaterials, vol. 27, no. 3, pp. 324-334, 2006.

[4] P. Xing, G. P. Robertson, M. D. Guiver, S. D. Mikhailenko, K. Wang, and S. Kaliaguine, "Synthesis and characterization of sulfonated poly(ether ether ketone) for proton exchange membranes," Journal of Membrane Science, vol. 229, no. 1-2, pp. 95-106, 2004.

[5] M. C. Sobieraj, S. M. Kurtz, and C. M. Rimnac, "Notch sensitivity of PEEK in monotonic tension," Biomaterials, vol. 30, no. 33, pp. 6485-6494, 2009. 
[6] C.-M. Han, E.-J. Lee, H.-E. Kim et al., "The electron beam deposition of titanium on polyetheretherketone (PEEK) and the resulting enhanced biological properties," Biomaterials, vol. 31, no. 13, pp. 3465-3470, 2010.

[7] V. A. Stadelmann, A. Terrier, and D. P. Pioletti, "Microstimulation at the bone-implant interface upregulates osteoclast activation pathways," Bone, vol. 42, no. 2, pp. 358-364, 2008.

[8] S. Ramakrishna, J. Mayer, E. Wintermantel, and K. W. Leong, "Biomedical applications of polymer-composite materials: a review," Composites Science and Technology, vol. 61, no. 9, pp. 1189-1224, 2001.

[9] J. Tams, F. R. Rozema, R. R. M. Bos, J. L. N. Roodenburg, P. G. J. Nikkels, and A. Vermey, "Poly(L-lactide) bone plates and screws for internal fixation of mandibular swing osteotomies," International Journal of Oral and Maxillofacial Surgery, vol. 25, no. 1, pp. 20-24, 1996.

[10] N. Scher, D. Poe, F. Kuchnir, C. Reft, R. Weichselbaum, and W. R. Panje, "Radiotherapy of the resected mandible following stainless steel plate fixation," The Laryngoscope, vol. 98, no. 5, pp. 561-563, 1988.

[11] A. J. Barton, R. D. Sagers, and W. G. Pitt, "Bacterial adhesion to orthopedic implant polymers," Journal of Biomedical Materials Research, vol. 30, no. 3, pp. 403-410, 1996.

[12] D. F. Williams, A. McNamara, and R. M. Turner, "Potential of polyetheretherketone (PEEK) and carbon-fibre-reinforced PEEK in medical applications," Journal of Materials Science Letters, vol. 6, no. 2, pp. 188-190, 1987.

[13] A. Schwitalla and W.-D. Müller, "PEEK dental implants: a review of the literature," Journal of Oral Implantology, vol. 39, no. 6, pp. 743-749, 2013.

[14] S. Yu, K. P. Hariram, R. Kumar, P. Cheang, and K. K. Aik, "In vitro apatite formation and its growth kinetics on hydroxyapatite/polyetheretherketone biocomposites," Biomaterials, vol. 26, no. 15, pp. 2343-2352, 2005.

[15] M. S. Abu Bakar, M. H. W. Cheng, S. M. Tang et al., “Tensile properties, tension-tension fatigue and biological response of polyetheretherketone-hydroxyapatite composites for loadbearing orthopedic implants," Biomaterials, vol. 24, no. 13, pp. 2245-2250, 2003.

[16] K. L. Wong, C. T. Wong, W. C. Liu et al., "Mechanical properties and in vitro response of strontium-containing hydroxyapatite/polyetheretherketone composites," Biomaterials, vol. 30, no. 23-24, pp. 3810-3817, 2009.

[17] G. L. Converse, T. L. Conrad, C. H. Merrill, and R. K. Roeder, "Hydroxyapatite whisker-reinforced polyetherketoneketone bone ingrowth scaffolds," Acta Biomaterialia, vol. 6, no. 3, pp. 856-863, 2010.

[18] G. L. Converse, W. Yue, and R. K. Roeder, "Processing and tensile properties of hydroxyapatite-whisker-reinforced polyetheretherketone," Biomaterials, vol. 28, no. 6, pp. 927-935, 2007.

[19] J. P. Fan, C. P. Tsui, C. Y. Tang, and C. L. Chow, "Influence of interphase layer on the overall elasto-plastic behaviors of HA/PEEK biocomposite," Biomaterials, vol. 25, no. 23, pp. 53635373, 2004.

[20] X. Wu, X. Liu, J. Wei, J. Ma, F. Deng, and S. Wei, "Nano$\mathrm{TiO}_{2} /$ PEEK bioactive composite as a bone substitute material: in vitro and in vivo studies," International Journal of Nanomedicine, vol. 7, pp. 1215-1225, 2012.

[21] H.-K. Tsou, P.-Y. Hsieh, C.-J. Chung, C.-H. Tang, T.-W. Shyr, and J.-L. He, "Low-temperature deposition of anatase $\mathrm{TiO} 2$ on medical grade polyetheretherketone to assist osseous integration," Surface and Coatings Technology, vol. 204, no. 6-7, pp. 1121-1125, 2009.

[22] Y. Zhao, H. M. Wong, W. Wang et al., "Cytocompatibility, osseointegration, and bioactivity of three-dimensional porous and nanostructured network on polyetheretherketone," Biomaterials, vol. 34, no. 37, pp. 9264-9277, 2013.

[23] L. L. Hench, R. J. Splinter, W. C. Allen, and T. K. Greenlee, "Bonding mechanisms at the interface of ceramic prosthetic materials," Journal of Biomedical Materials Research, vol. 5, no. 6, pp. 117-141, 1972.

[24] B. Kasemo, "Biological surface science," Surface Science, vol. 500, no. 1-3, pp. 656-677, 2002.

[25] B. Kasemo and J. Lausmaa, "Material-tissue interfaces: the role of surface properties and processes," Environmental Health Perspectives, vol. 102, no. 5, pp. 41-45, 1994.

[26] M. Mrksich, "A surface chemistry approach to studying cell adhesion," Chemical Society Reviews, vol. 29, no. 4, pp. 267-273, 2000.

[27] G. Altankov and T. Groth, "Reorganization of substratumbound fibronectin on hydrophilic and hydrophobic materials is related to biocompatibility," Journal of Materials Science: Materials in Medicine, vol. 5, no. 9-10, pp. 732-737, 1994.

[28] O. Noiset, Y.-J. Schneider, and J. Marchand-Brynaert, "Surface modification of poly(aryl ether ether ketone) (PEEK) film by covalent coupling of amines and amino acids through a spacer arm," Journal of Polymer Science Part A: Polymer Chemistry, vol. 35, no. 17, pp. 3779-3790, 1997.

[29] A. Katzer, H. Marquardt, J. Westendorf, J. V. Wening, and G. von Foerster, "Polyetheretherketone-cytotoxicity and mutagenicity in vitro," Biomaterials, vol. 23, no. 8, pp. 1749-1759, 2002.

[30] A. H. C. Poulsson and R. G. Richards, "Chapter 10-surface modification techniques of polyetheretherketone, including plasma surface treatment," in PEEK Biomaterials Handbook, S. M. Kurtz, Ed., chapter 10, pp. 145-161, William Andrew, Oxford, UK, 2012.

[31] J. Marchand-Brynaert, G. Pantano, and O. Noiset, "Surface fluorination of PEEK film by selective wet-chemistry," Polymer, vol. 38, no. 6, pp. 1387-1394, 1997.

[32] O. Noiset, Y. J. Schneider, and J. Marchand-Brynaert, "Fibronectin adsorption or/and covalent grafting on chemically modified PEEK film surfaces," Journal of Biomaterials Science, Polymer Edition, vol. 10, no. 6, pp. 657-677, 1999.

[33] O. Noiset, Y.-J. Schneider, and J. Marchand-Brynaert, "Adhesion and growth of $\mathrm{CaCo} 2$ cells on surface-modified PEEK substrata," Journal of Biomaterials Science, Polymer Edition, vol. 11, no. 7, pp. 767-786, 2000.

[34] M. Pino, N. Stingelin, and K. E. Tanner, "Nucleation and growth of apatite on $\mathrm{NaOH}$-treated PEEK, HDPE and UHMWPE for artificial cornea materials," Acta Biomaterialia, vol. 4, no. 6, pp. 1827-1836, 2008.

[35] E. Occhiello, M. Morra, G. L. Guerrini, and F. Garbassi, "Adhesion properties of plasma-treated carbon/PEEK composites," Composites, vol. 23, no. 3, pp. 193-200, 1992.

[36] J. Comyn, L. Mascia, G. Xiao, and B. M. Parker, "Plasmatreatment of polyetheretherketone (PEEK) for adhesive bonding," International Journal of Adhesion and Adhesives, vol. 16, no. 2, pp. 97-104, 1996.

[37] S.-W. Ha, M. Kirch, F. Birchler et al., "Surface activation of polyetheretherketone (PEEK) and formation of calcium phosphate coatings by precipitation," Journal of Materials Science: Materials in Medicine, vol. 8, no. 11, pp. 683-690, 1997. 
[38] K. Schröder, A. Meyer-Plath, D. Keller, and A. Ohl, "On the applicability of plasma assisted chemical micropatterning to different polymeric biomaterials," Plasmas and Polymers, vol. 7, no. 2, pp. 103-125, 2002.

[39] D. Briem, S. Strametz, K. Schröoder et al., "Response of primary fibroblasts and osteoblasts to plasma treated polyetheretherketone (PEEK) surfaces," Journal of Materials Science: Materials in Medicine, vol. 16, no. 7, pp. 671-677, 2005.

[40] F. Awaja, D. V. Bax, S. Zhang, N. James, and D. R. McKenzie, "Cell adhesion to PEEK treated by plasma immersion ion implantation and deposition for active medical implants," Plasma Processes and Polymers, vol. 9, no. 4, pp. 355-362, 2012.

[41] A. H. C. Poulsson, D. Eglin, S. Zeiter et al., "Osseointegration of machined, injection moulded and oxygen plasma modified PEEK implants in a sheep model," Biomaterials, vol. 35 , no. 12 , pp. 3717-3728, 2014.

[42] H. Wang, T. Lu, F. Meng, H. Zhu, and X. Liu, "Enhanced osteoblast responses to poly ether ether ketone surface modified by water plasma immersion ion implantation," Colloids and Surfaces B: Biointerfaces, vol. 117, pp. 89-97, 2014.

[43] Z. Novotna, A. Reznickova, S. Rimpelova, M. Vesely, Z. Kolska, and V. Svorcik, "Tailoring of PEEK bioactivity for improved cell interaction: plasma treatment in action," RSC Advances, vol. 5, no. 52, pp. 41428-41436, 2015.

[44] J. Waser-Althaus, A. Salamon, M. Waser et al., "Differentiation of human mesenchymal stem cells on plasma-treated polyetheretherketone," Journal of Materials Science: Materials in Medicine, vol. 25, no. 2, pp. 515-525, 2014.

[45] R. Comesaña, F. Quintero, F. Lusquiños et al., "Laser cladding of bioactive glass coatings," Acta Biomaterialia, vol. 6, no. 3, pp. 953-961, 2010.

[46] P. Laurens, B. Sadras, F. Décobert, F. Aréfi-Khonsari, and J. Amouroux, "Laser-induced surface modifications of poly(ether ether ketone): influence of the excimer laser wavelength," Journal of Adhesion Science and Technology, vol. 13, no. 9, pp. 983-997, 1999.

[47] P. Laurens, M. Ould Bouali, F. Meducin, and B. Sadras, "Characterization of modifications of polymer surfaces after excimer laser treatments below the ablation threshold," Applied Surface Science, vol. 154-155, pp. 211-216, 2000.

[48] P. Laurens, B. Sadras, F. Decobert, F. Arefi-Khonsari, and J. Amouroux, "Enhancement of the adhesive bonding properties of PEEK by excimer laser treatment," International Journal of Adhesion and Adhesives, vol. 18, no. 1, pp. 19-27, 1998.

[49] A. Riveiro, R. Soto, R. Comesaña et al., "Laser surface modification of PEEK," Applied Surface Science, vol. 258, no. 23, pp. 9437-9442, 2012.

[50] J. Khoury, S. R. Kirkpatrick, M. Maxwell, R. E. Cherian, A. Kirkpatrick, and R. C. Svrluga, "Neutral atom beam technique enhances bioactivity of PEEK," Nuclear Instruments and Methods in Physics Research Section B: Beam Interactions with Materials and Atoms, vol. 307, pp. 630-634, 2013.

[51] A. Kirkpatrick, S. Kirkpatrick, M. Walsh et al., "Investigation of accelerated neutral atom beams created from gas cluster ion beams," Nuclear Instruments and Methods in Physics Research, Section B: Beam Interactions with Materials and Atoms, vol. 307, pp. 281-289, 2013.

[52] I. Mathieson and R. H. Bradley, "Improved adhesion to polymers by UV/ozone surface oxidation," International Journal of Adhesion and Adhesives, vol. 16, no. 1, pp. 29-31, 1996.
[53] H. Garg, G. Bedi, and A. Garg, "Implant surface modifications: a review," Journal of Clinical and Diagnostic Research, vol. 6, no. 2, pp. 319-324, 2012.

[54] S.-W. Ha, J. Mayer, B. Koch, and E. Wintermantel, "Plasmasprayed hydroxylapatite coating on carbon fibre reinforced thermoplastic composite materials," Journal of Materials Science: Materials in Medicine, vol. 5, no. 6-7, pp. 481-484, 1994.

[55] S.-W. Ha, A. Gisep, J. Mayer, E. Wintermantel, H. Gruner, and M. Wieland, "Topographical characterization and microstructural interface analysis of vacuum-plasma-sprayed titanium and hydroxyapatite coatings on carbon fibrereinforced poly(etheretherketone)," Journal of Materials Science: Materials in Medicine, vol. 8, no. 12, pp. 891-896, 1997.

[56] A. Rabiei and S. Sandukas, "Processing and evaluation of bioactive coatings on polymeric implants," Journal of Biomedical Materials Research-Part A, vol. 101, no. 9, pp. 2621-2629, 2013.

[57] S. Beauvais and O. Decaux, "Plasma sprayed biocompatible coatings on PEEK implants," in Proceedings of the International Thermal Spray Conference, B. R. Marple, Ed., Beijing, China, May 2007.

[58] J. H. Lee, H. L. Jang, K. M. Lee et al., "In vitro and in vivo evaluation of the bioactivity of hydroxyapatite-coated polyetheretherketone biocomposites created by cold spray technology," Acta Biomaterialia, vol. 9, no. 4, pp. 6177-6187, 2013.

[59] B.-D. Hahn, D.-S. Park, J.-J. Choi et al., "Osteoconductive hydroxyapatite coated PEEK for spinal fusion surgery," Applied Surface Science, vol. 283, pp. 6-11, 2013.

[60] S. Barkarmo, A. Wennerberg, M. Hoffman et al., "Nanohydroxyapatite-coated PEEK implants: a pilot study in rabbit bone," Journal of Biomedical Materials Research Part A, vol. 101, no. 2, pp. 465-471, 2013.

[61] D. Almasi, S. Izman, M. Assadian, M. Ghanbari, and M. R. Abdul Kadir, "Crystalline ha coating on peek via chemical deposition," Applied Surface Science, vol. 314, pp. 1034-1040, 2014.

[62] D. Almasi, S. Izman, M. Sadeghi et al., "In vitro evaluation of bioactivity of chemically deposited hydroxyapatite on polyether ether ketone," International Journal of Biomaterials, vol. 2015, Article ID 475435, 5 pages, 2015.

[63] M.-H. Chi, H.-K. Tsou, C.-J. Chung, and J.-L. He, "Biomimetic hydroxyapatite grown on biomedical polymer coated with titanium dioxide interlayer to assist osteocompatible performance," Thin Solid Films, vol. 549, pp. 98-102, 2013.

[64] C.-M. Han, T.-S. Jang, H.-E. Kim, and Y.-H. Koh, “Creation of nanoporous $\mathrm{TiO}_{2}$ surface onto polyetheretherketone for effective immobilization and delivery of bone morphogenetic protein," Journal of Biomedical Materials Research A, vol. 102, no. 3, pp. 793-800, 2014.

[65] A. G. R. Wieling, "Osteointegrative surfaces for CF/PEEK implants," European Cells and Materials, vol. 17, supplement 1, p. 10, 2009.

[66] S.-W. Ha, K.-L. Eckert, E. Wintermantel, H. Gruner, M. Guecheva, and H. Vonmont, "NaOH treatment of vacuum-plasma-sprayed titanium on carbon fibre-reinforced poly(etheretherketone)," Journal of Materials Science: Materials in Medicine, vol. 8, no. 12, pp. 881-886, 1997.

[67] D. M. Devine, J. Hahn, R. G. Richards, H. Gruner, R. Wieling, and S. G. Pearce, "Coating of carbon fiber-reinforced polyetheretherketone implants with titanium to improve bone apposition," Journal of Biomedical Materials Research B: Applied Biomaterials, vol. 101, no. 4, pp. 591-598, 2013. 
[68] S. D. Cook and A. M. Rust-Dawicki, "Preliminary evaluation of titanium-coated PEEK dental implants," The Journal of Oral Implantology, vol. 21, no. 3, pp. 176-181, 1995.

[69] T. Joseph Dennes and J. Schwartz, "A nanoscale adhesion layer to promote cell attachment on PEEK," Journal of the American Chemical Society, vol. 131, no. 10, pp. 3456-3457, 2009.

[70] H. Wang, M. Xu, W. Zhang et al., "Mechanical and biological characteristics of diamond-like carbon coated poly aryl-etherether-ketone," Biomaterials, vol. 31, no. 32, pp. 8181-8187, 2010.

[71] M. S. Abu Bakar, P. Cheang, and K. A. Khor, "Thermal processing of hydroxyapatite reinforced polyetheretherketone composites," Journal of Materials Processing Technology, vol. 8990, pp. 462-466, 1999.

[72] K. H. Tan, C. K. Chua, K. F. Leong et al., "Scaffold development using selective laser sintering of polyetheretherketonehydroxyapatite biocomposite blends," Biomaterials, vol. 24, no. 18, pp. 3115-3123, 2003.

[73] K. H. Tan, C. K. Chua, K. F. Leong et al., "Selective laser sintering of biocompatible polymers for applications in tissue engineering," Bio-Medical Materials and Engineering, vol. 15, no. 1-2, pp. 113-124, 2005.

[74] K. H. Tan, C. K. Chua, K. F. Leong, M. W. Naing, and C. M. Cheah, "Fabrication and characterization of three-dimensional poly(ether-ether-ketone)/-hydroxyapatite biocomposite scaffolds using laser sintering," Proceedings of the Institution of Mechanical Engineers Part H: Journal of Engineering in Medicine, vol. 219, no. 3, pp. 183-194, 2005.

[75] R. K. Roeder, S. M. Smith, T. L. Conrad, N. J. Yanchak, C. H. Merrill, and G. L. Converse, "Porous and bioactive PEEK implants for interbody spinal fusion," Journal of Advanced Materials and Processing, vol. 167, no. 10, pp. 46-48, 2009.

[76] M. S. Abu Bakar, P. Cheang, and K. A. Khor, "Tensile properties and microstructural analysis of spheroidized hydroxyapatitepoly (etheretherketone) biocomposites," Materials Science and Engineering A, vol. 345, no. 1-2, pp. 55-63, 2003.

[77] L. Wang, L. Weng, S. Song, and Q. Sun, "Mechanical properties and microstructure of polyetheretherketone-hydroxyapatite nanocomposite materials," Materials Letters, vol. 64, no. 20, pp. 2201-2204, 2010.

[78] L. Wang, L. Weng, S. Song, Z. Zhang, S. Tian, and R. $\mathrm{Ma}$, "Characterization of polyetheretherketone-hydroxyapatite nanocomposite materials," Materials Science and Engineering A, vol. 528, no. 10-11, pp. 3689-3696, 2011.

[79] C. Hengky, B. Kelsen, and P. Saraswati, "Mechanical and biological characterization of pressureless sintered hydroxapatitepolyetheretherketone biocomposite," in 13th International Conference on Biomedical Engineering: ICBME 2008 3-6 December 2008 Singapore, vol. 23 of IFMBE Proceedings, pp. 261-264, Springer, Berlin, Germany, 2009.

[80] K. Li, C. Y. Yeung, K. W. K. Yeung, and S. C. Tjong, "Sintered hydroxyapatite/polyetheretherketone nanocomposites: mechanical behavior and biocompatibility," Advanced Engineering Materials, vol. 14, no. 4, pp. B155-B165, 2012.

[81] R. Ma, L. Weng, X. Bao, S. Song, and Y. Zhang, "In vivo biocompatibility and bioactivity of in situ synthesized hydroxyapatite/polyetheretherketone composite materials," Journal of Applied Polymer Science, vol. 127, no. 4, pp. 2581-2587, 2013.

[82] R. Ma, L. Weng, X. Bao, Z. Ni, S. Song, and W. Cai, "Characterization of in situ synthesized hydroxyapatite/ polyetheretherketone composite materials," Materials Letters, vol. 71, pp. 117-119, 2012.
[83] R. Ma, L. Weng, L. Fang, Z. Luo, and S. Song, "Structure and mechanical performance of in situ synthesized hydroxyapatite/polyetheretherketone nanocomposite materials," Journal of Sol-Gel Science and Technology, vol. 62, no. 1, pp. 52-56, 2012.

[84] L. Petrovic, D. Pohle, H. Münstedt, T. Rechtenwald, K. A. Schlegel, and S. Rupprecht, "Effect of $\beta$ TCP filled polyetheretherketone on osteoblast cell proliferation in vitro," Journal of Biomedical Science, vol. 13, no. 1, pp. 41-46, 2006.

[85] D. Pohle, S. Ponader, T. Rechtenwald et al., "Processing of threedimensional laser sintered polyetheretherketone composites and testing of osteoblast proliferation in vitro," Macromolecular Symposia, vol. 253, pp. 65-70, 2007.

[86] C. Von Wilmowsky, E. Vairaktaris, D. Pohle et al., "Effects of bioactive glass and $\beta$-TCP containing three-dimensional laser sintered polyetheretherketone composites on osteoblasts in vitro," Journal of Biomedical Materials Research A, vol. 87, no. 4, pp. 896-902, 2008.

[87] C. Von Wilmonsky, R. Lutz, U. Meisel et al., "In Vivo evaluation of $\beta$-TCP containing 3D laser sintered poly(ether ether ketone) composites in pigs," Journal of Bioactive and Compatible Polymers, vol. 24, no. 2, pp. 169-184, 2009.

[88] Y. Zhang, L. Hao, M. M. Savalani, R. A. Harris, L. Di Silvio, and K. E. Tanner, "In vitro biocompatibility of hydroxyapatitereinforced polymeric composites manufactured by selective laser sintering," Journal of Biomedical Materials Research A, vol. 91, no. 4, pp. 1018-1027, 2009.

[89] T. W. Lin, A. A. Corvelli, C. G. Frondoza, J. C. Roberts, and D. S. Hungerford, "Glass peek composite promotes proliferation and osteocalcin production of human osteoblastic cells," Journal of Biomedical Materials Research, vol. 36, no. 2, pp. 137-144, 1997.

[90] A. A. Corvelli, J. C. Roberts, P. J. Biermann, and J. H. Cranmer, "Characterization of a peek composite segmental bone replacement implant," Journal of Materials Science, vol. 34, no. 10, pp. 2421-2431, 1999.

[91] I. Y. Kim, A. Sugino, K. Kikuta, C. Ohtsuki, and S. B. Cho, "Bioactive composites consisting of PEEK and calcium silicate powders," Journal of Biomaterials Applications, vol. 24, no. 2, pp. 105-118, 2009.

[92] S. M. Tang, P. Cheang, M. S. AbuBakar, K. A. Khor, and K. Liao, "Tension-tension fatigue behavior of hydroxyapatite reinforced polyetheretherketone composites," International Journal of Fatigue, vol. 26, no. 1, pp. 49-57, 2004.

[93] G. L. Converse, T. L. Conrad, and R. K. Roeder, "Fatigue life of hydroxyapatite whisker reinforced polyetherketoneketone," Transactions of the Society for Biomaterials, vol. 32, p. 584, 2009.

[94] G. L. Converse, T. L. Conrad, and R. K. Roeder, "Mechanical properties of hydroxyapatite whisker reinforced polyetherketoneketone composite scaffolds," Journal of the Mechanical Behavior of Biomedical Materials, vol. 2, no. 6, pp. 627-635, 2009. 

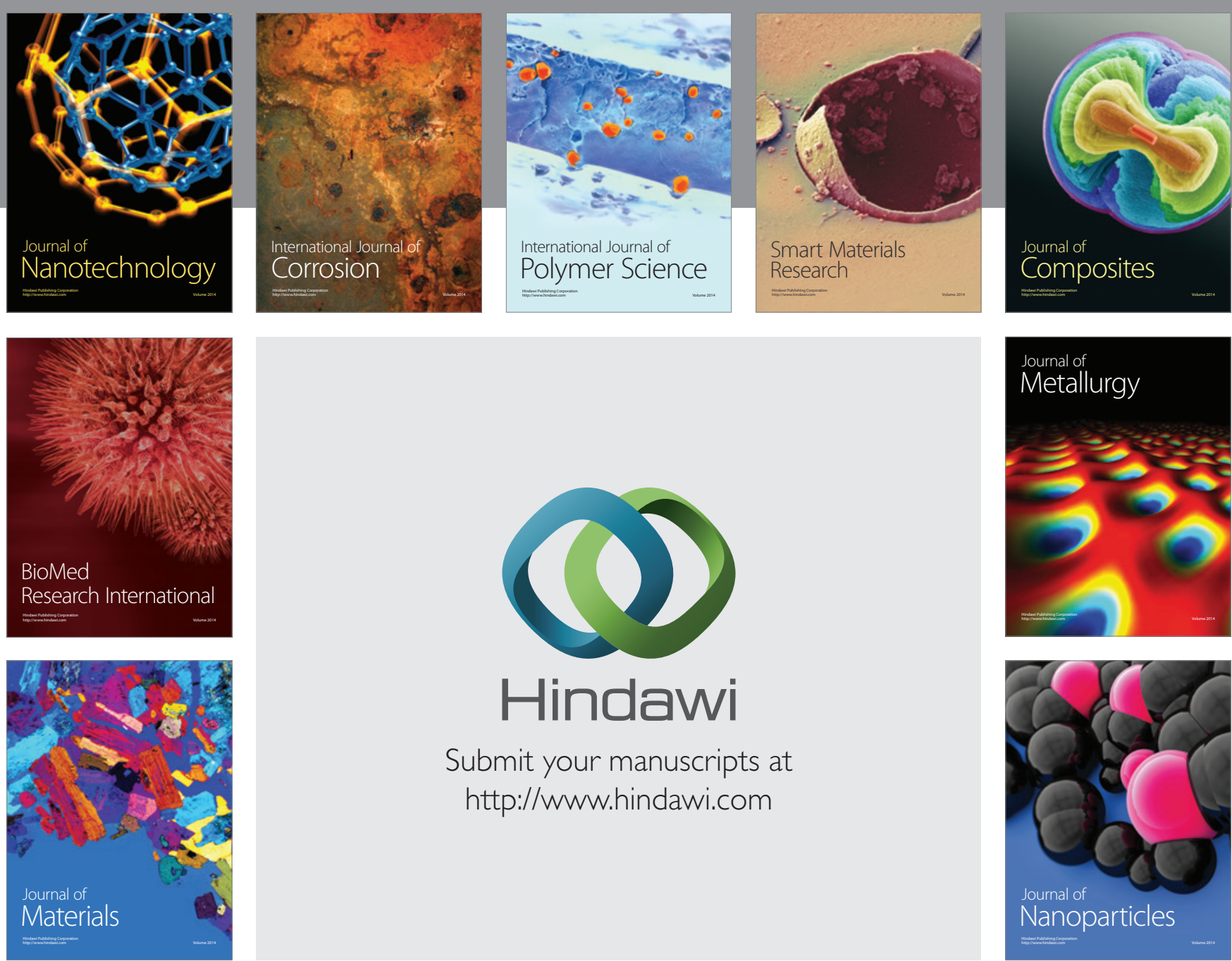

\section{Hindawi}

Submit your manuscripts at

http://www.hindawi.com

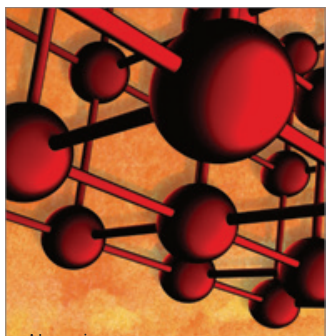

Materials Science and Engineering
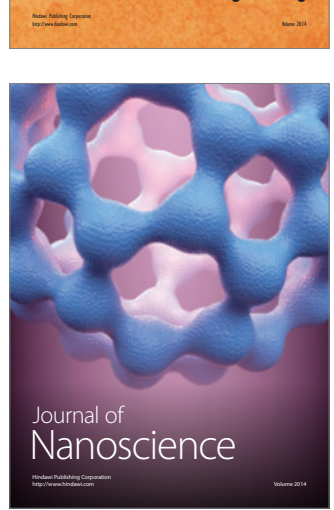
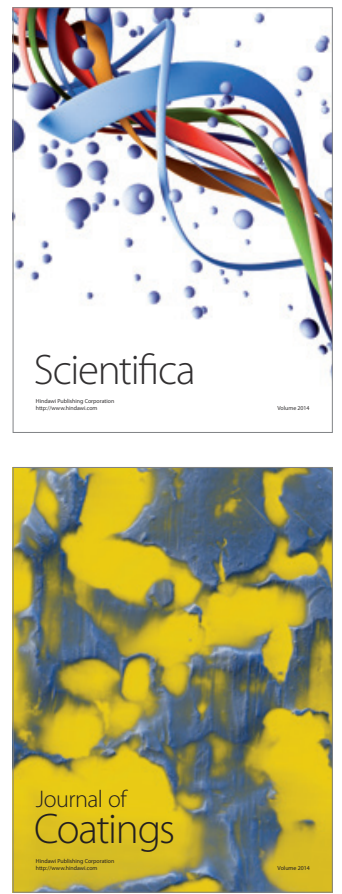
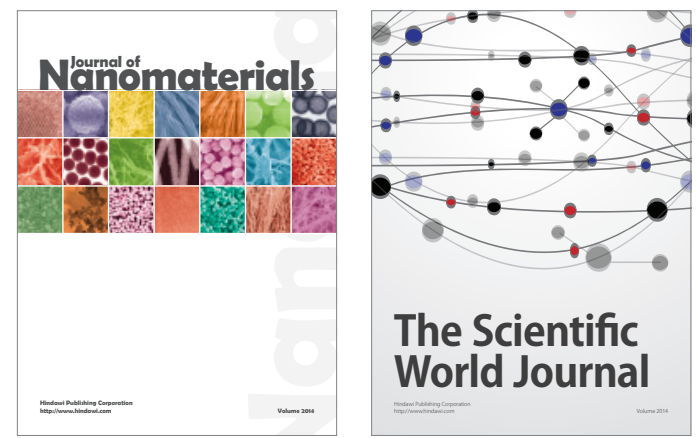

The Scientific World Journal
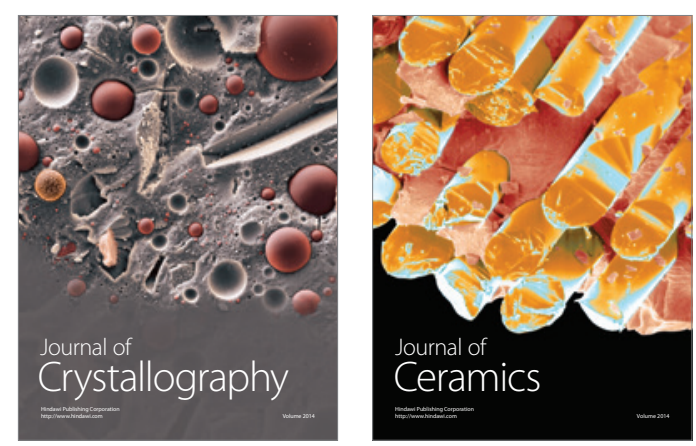
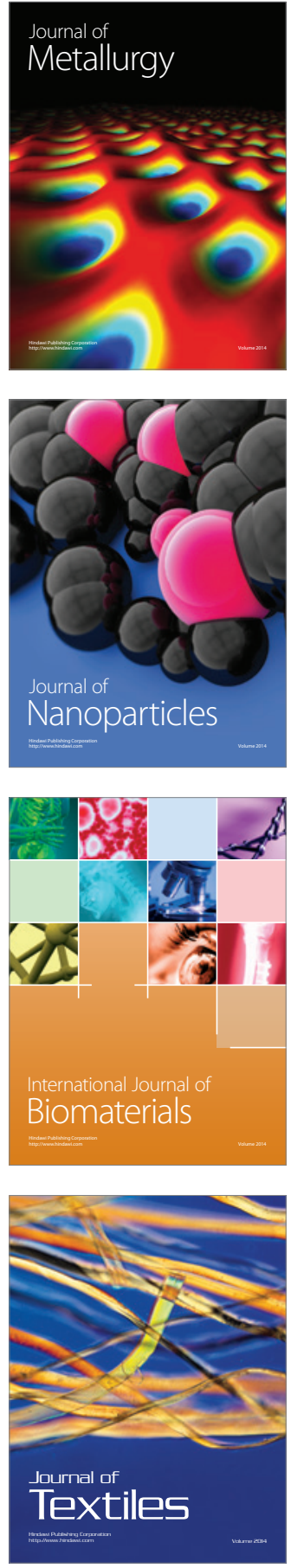